\title{
Portraits in pediatric leadership: Maria Montessori
}

\author{
Richard B. Gunderman ${ }^{1}$
}

Received: 28 September 2019 /Revised: 28 September 2019 / Accepted: 11 October 2019 / Published online: 5 November 2019

(C) Springer-Verlag GmbH Germany, part of Springer Nature 2019

She broke gender barriers by studying at an all-male technical school, became one of the first women in her nation to graduate from medical school, gave her only child to be raised by farmers so she could continue her work, began her career as an educator working with disabled students, introduced kid-size materials in the education of children, refused to bow to the will of a dictator who initially supported her, and worked closely with two Indian Nobel laureates. In addition, she became one of the most influential educators of the 20th century. Her name was Maria Montessori.

Although she achieved worldwide fame, Montessori's incredible life story is not widely known. This is a pity. Her educational philosophy represents an important counterpoint to today's educational preferences for prescribed curricula, programmed instruction, and standardized evaluation methods, such as multiple-choice exams. Montessori put children first and insisted that everything else - curriculum, instructional methods, and assessment - exist only to serve them. Moreover, her biography offers much-needed inspiration to teachers and parents.

Born in Italy in 1870, Montessori grew up primarily in Rome, where she performed well as a student [1]. Her father expected her to pursue a career in teaching, but instead she entered an all-male technical school, where she studied engineering and mathematics and graduated in 1890. Again bucking gender norms, she then enrolled in medical school. Because she was a woman, she was allowed to enter classrooms only after her male colleagues had been seated and could participate in cadaver dissections only after hours, when the other students had left. Despite these obstacles, she graduated in 1896 with honors.

Her medical training completed, Montessori began working with children with disabilities, serving as an advocate for

Richard B. Gunderman

rbgunder@iu.edu

1 Department of Radiology, Indiana University School of Medicine, 702 North Barnhill Drive, Room 1053, Indianapolis, IN 46202, USA their rights and the rights of their families. In 1898, her only child, Mario, was born. Knowing that she would be unable to continue her career if she married, she elected instead to remain single, keep the child's father a secret, and place her son in foster care with a family in the countryside. It was not until more than a decade later, when Mario was a teenager, that the two were permanently reunited. She joined a newly formed league to protect children with mental disabilities, eventually joining the faculty of a school designed to train the teachers of such students.

In 1906, Montessori gave up a university chair position to organize the education of low-income children in Rome. Known as Casa dei Bambini ("Children's House"), it was here that Montessori began to develop and apply her educational principles. She procured child-size equipment such as tables, chairs and chalkboards. She observed that children often became spontaneously absorbed in play and learning, without direction from teachers. She determined that children were intrinsically motivated to learn, that they enjoyed learning, and that left largely to their own devices, they could develop mastery of a variety of activities, such as conversation, reading and writing, and artistic expression.

When children began reading and writing at the age of 4 5 years, Children's Houses began to spring up in other locations, and in 1909 Montessori was offering the first training courses on her methods for teachers. Soon she found herself so busy developing and disseminating her educational approach that she gave up the practice of medicine entirely. Within a few years, Montessori schools could be found around the world, from Western Europe to Syria, India, China, Australia, Japan and the United States. In addition to offering courses, she published numerous books and manuals that outlined her approach and were translated into many languages.

Montessori moved to Spain in 1915 but traveled widely throughout Europe. Initially popular with Italian dictator Benito Mussolini and his Fascist Party, she was soon appointed president of her own society. But beginning around 1930 she fell out of favor, in part because she refused to allow 
her schools to participate in pledges and songs designed to promote the ruling party's political objectives. Moreover, Montessori was an indefatigable proponent of education as a means of securing peace, which brought her into conflict with Mussolini's militaristic plans. By 1936, the government had terminated its Montessori-inspired educational programs throughout the country.

In the late 1930s, Montessori and her son, who was now a close collaborator, journeyed to India to participate in the education of children in poverty. While they were there, World War II broke out. As Italians, the Montessoris were detained; however, they were released after several months and remained in India until the war ended. Montessori's approach strongly influenced Nobel laureate Rabindranath Tagore, to whom she wrote: "I am certain that my ideas, which are founded only on love for the children, will find a good welcome." She and eventual Nobel laureate Mohandas Gandhi first met in 1931 and worked to promote the belief that peace is possible only if it begins with children.

Montessori died in her adopted country of the Netherlands in 1952 at the age of 81 . Today her influence lives on in many ways [2]. In the United States, there are approximately 5,000 Montessori schools educating more than 1 million students, and similar programs can be found in more than 140 countries worldwide. A remarkably diverse group of notable people are Montessori alumni, including chef Julia Child, Google founders Larry Page and Sergey Brin, basketball player Stephen Curry, and actor Helen Hunt. In 2018, alumnus and Amazon founder Jeff Bezos funded an initiative called Day One Academies, providing $\$ 2$ billion to fund Montessori education for low-income students [3].
Montessori's story holds many lessons for aspiring pediatric radiology leaders. Don't let stereotypes based in such arbitrary characteristics as gender stand in your way Montessori showed that it is possible to surmount them. Base everything you do in a self-transcending higher commitment - in her case, an unwavering vow to put the development of children first. Seek out the best people to learn from and collaborate with, even if they are far away, which for her included two Indian Nobel laureates. And finally, regard your mission not as self-promotion but as educating others about enhanced purposes and means for your work - in her case, child-focused education.

\section{Compliance with ethical standards}

Conflicts of interest None

\section{References}

1. Standing EM (1998) Maria Montessori: her life and work. Plume, New York

2. Lillard PP (1996) Montessori today. Schocken Books, New York

3. Weise K (2018) Jeff and MacKenzie Bezos pledge \$2 billion for homeless and preschoolers. The New York Times. https://www. nytimes.com/2018/09/13/technology/jeff-and-mackenzie-bezospledge-2-billion-for-homeless-and-preschoolers.html. Accessed 8 Oct 2019

Publisher's note Springer Nature remains neutral with regard to jurisdictional claims in published maps and institutional affiliations. 